\title{
Morphometric Analysis for Prioritization using Remote Sensing and GIS Techniques in a Hilly Catchment in the State of Uttarakhand, India
}

\author{
Deepak Khare, Arun Mondal, Prabhash Kumar Mishra, \\ Sananda Kundu and Pramod Kumar Meena*
}

Department of Water Resources Development \& Management, Indian Institute of Technology, Roorkee-247667 (U.A.), India; pramodcae@gmail.com

\begin{abstract}
Drainage pattern study utilizing Remote Sensing (RS) and Geographical Information System (GIS) has proved to be an efficient and quick tool, nowadays, for water resources planning, conservation and management. In the present study morphological features of 'Bhilanganga' drainage basin are being extracted utilizing satellite imagery and analyzed for assessing the drainage pattern and identifying priority sub-basins for conservation measures as well. The basin morphometric parameters such as linear and aerial aspects were determined and computed using ArcInfo software. The region is a part of Uttarakhand state of India, a hilly catchment in the lower Himalayan range covering an area of 1465.38 $\mathrm{km}^{2}$. The area extends from 30019'41"N to 30o52'42"N latitude and from 78o29'13"E to 79o2' '” E longitude. The entire area is sub-divided into eight sub-basins ranging in area from $91.91 \mathrm{~km} 2$ to $465.29 \mathrm{~km}^{2}$. The pattern of drainage in the area is dendritic to sub-dendritic and the stream ordering ranges from order I to VII. The drainage density indicates a coarser drainage ranging from 1.68 to $2.34 \mathrm{~km} / \mathrm{km}^{2}$. The entire area is the normal basin category as observed from the bifurcation ratio. The RS and GIS techniques have proven to be very useful in this case of morphometric analysis, as the study area is a hilly catchment located in a difficult terrain.
\end{abstract}

Keywords: Bhilanganga Sub-basin, Bifurcation Ratio, Drainage Density, GIS, Morphometry, Remote Sensing

\section{Introduction}

Morphometry is the measurement and mathematical analysis of the configuration of the earth surface, shape and dimension of land forms ${ }^{1-4}$. The morphometric parameters are evaluated through measurement of linear, areal and relief aspects of the basin. Morphometric analysis involves quantifying morphometric variables which is very useful in studies such as regional flood frequency analysis, hydrologic modeling, watershed prioritization, natural resources conservation and management, drainage basin evaluation, etc. The bearing of geomorphology on hydrology is very significant. Geomorphological parameters of a basin represent the hydrologic behavior closely. In many regions most of the basins are either ungauged or difficult to access, therefore, the study on geomorphologic features of basins become much more important. The estimation of such parameters gains further importance in case of hilly catchment since direct measurement of hydrologic data is tedious and difficult ${ }^{5}$. Recent Studies reveled that some of the model inputs related to land use/ land cover, soil etc. have been successfully derived from remotely sensed data, and modeling was carried out in GIS environment ${ }^{6-8}$. Remote Sensing has the ability of obtaining synoptic view of larger area in each pass and is very useful in analyzing drainage morphometry ${ }^{2,9}$.

${ }^{*}$ Author for correspondence 
The quantitative measurements of morphologic parameters of different basins have been carried out by various researchers across the world using conventional methods ${ }^{10-12}$. Many researchers around the world and particularly from India have attempted studies on geomorphological analysis using RS and GIS techniques. These are efficient and less time consuming.

Nautiya ${ }^{13}$ evaluated the morphometric parameters of a drainage sub basin (Khairkuli) using aerial photographs in the district of Dehradun in the state of U.P. (now Uttarakhand state), India. The parameters worked out include bifurcation ratio, stream length, form factor, circulatory ratio, elongation ratio, drainage density, constant of channel maintenance, and stream frequency. National Institute of Hydrology ${ }^{5}$ has carried out morphometric analysis of Suddagedda basin in the state of Andhra Pradesh and many more in different parts of India. $\mathrm{Nag}^{9}$ conducted morphometric analysis in the Chak sub-basin of Purulia district, West Bengal, one of the most drought affected area in the region using Landsat TM and IRS LISS-2A imageries. Vittala et al. ${ }^{14}$ attempted morphometric analysis of nine sub-watersheds in the Paragada area of Tumkur district, Andhra Pradesh using IRS 1C and IRS 1D satellite images. Rudraiah et al. ${ }^{2}$ have undertaken morphometric analysis in four sub-basins of Kagna River in the Gulbarga district of Karnataka state, India using ArcInfo and Arcview GIS softwares. Nageswara Rao et al..$^{15}$ analyzed the morphological parameters of Gostani river basin in the state of Andhra Pradesh, India using spatial information technology i.e. RS, GIS and global positioning system. Mishra and Nagarajan ${ }^{16}$ have undertaken a case study on morphometric analysis and sub-watershed prioritization using RS and GIS in the Kalahandi district of Odisha state, India. In recent times, Malik et al. ${ }^{17}$ have carried out the morphometric analysis considering watershed as the basic unit of measurement in the Lidder catchment in Kashmir valley using GIS. All the researchers have arrived at the conclusion that RS and GIS techniques have emerged as a powerful tool in the recent years for analyzing morphometric parameters correctly and with less time. Chopra et al. ${ }^{18}$ attempted the same at subwatershed level in the Gurdaspur district of Punjab state, India using RS and GIS software. GIS and remote sensing techniques are of important use in characterization and prioritization of watershed due to spatial analysis and computation of soil erosion loss ${ }^{19-21}$ presented mapping, monitoring and prioritizing the areas based on their susceptibility to degradation using remote sensing and GIS techniques.

The present study has examined the utility of RS and GIS in morphometric analysis in a hilly catchment. Finally, prioritization rating of eight micro-basins of the Bhilanganga basin is carried out through ranking the computed morphologic parameters. The micro-basin with the lowest ranking is given the highest priority in terms of erosion and suggested for conservation measures urgently.

\section{Materials and Methods}

The study area Bhilanganga is a hilly catchment of the lower Himalayan range situated in the state of Uttarakhand, India. It covers an area of $1465.38 \mathrm{~km} 2$ and lies between 78029'13"E to 79o2'9"E longitude and $30 \circ 19^{\prime} 41^{\prime \prime} \mathrm{N}$ to $30052^{\prime} 42^{\prime \prime} \mathrm{N}$ latitude. The annual rainfall in the region is about $1000-2000 \mathrm{~mm}$. The maximum rainfall is observed in the monsoon months. The region witnesses comparatively cooler climate than the main land of India with maximum temperature ranges from 30 to $36^{\circ} \mathrm{C}$ while minimum between 0 to $80^{\circ} \mathrm{C}$. The relative humidity is high in the monsoon season generally exceeding $70 \%$. The climate of the area is mainly tropical monsoon type where maximum rainfall occurs in the monsoon months of June to October like most of India. Steep valley slopes are very common here and because of these, landslide and debris flow is quite frequent. The population density is very less. The location map is given in the Figure 1.

Survey of India (SOI) toposheets of 53J/5, J/6, J/7, J/9, $J / 10, J / 11, J / 13, J / 14, J / 15$ and $53 \mathrm{~N} / 1, \mathrm{~N} / 2, \mathrm{~N} / 3$ are used in the study with 1:50000 scale as reference maps. The Landsat TM satellite image ( $21^{\text {st }}$ January, 2010) is used to get the drainage pattern of different orders of the basin.

Morphometric analysis of a basin requires delineation of the basin boundary and existing drainage network of different extent and patterns. SOI toposheets on 1:50000 scale and Landsat TM data were utilized for digitization and updation of drainage networks of all existing orders after geometric rectification to global coordinate system using digital image processing software (ERDAS IMAGINE ver. 9.2) and GIS software (ArcInfo ver. 9.3).

The order was given to each stream by following Strahler ${ }^{24}$ stream ordering technique. In the present study the entire sub basin is sub-divided into eight microbasins viz.SWS-1, SWS-2, SWS-3, SWS-4, SWS-5, SWS-6, SWS-7, and SWS-8. Various morphometric parameters 


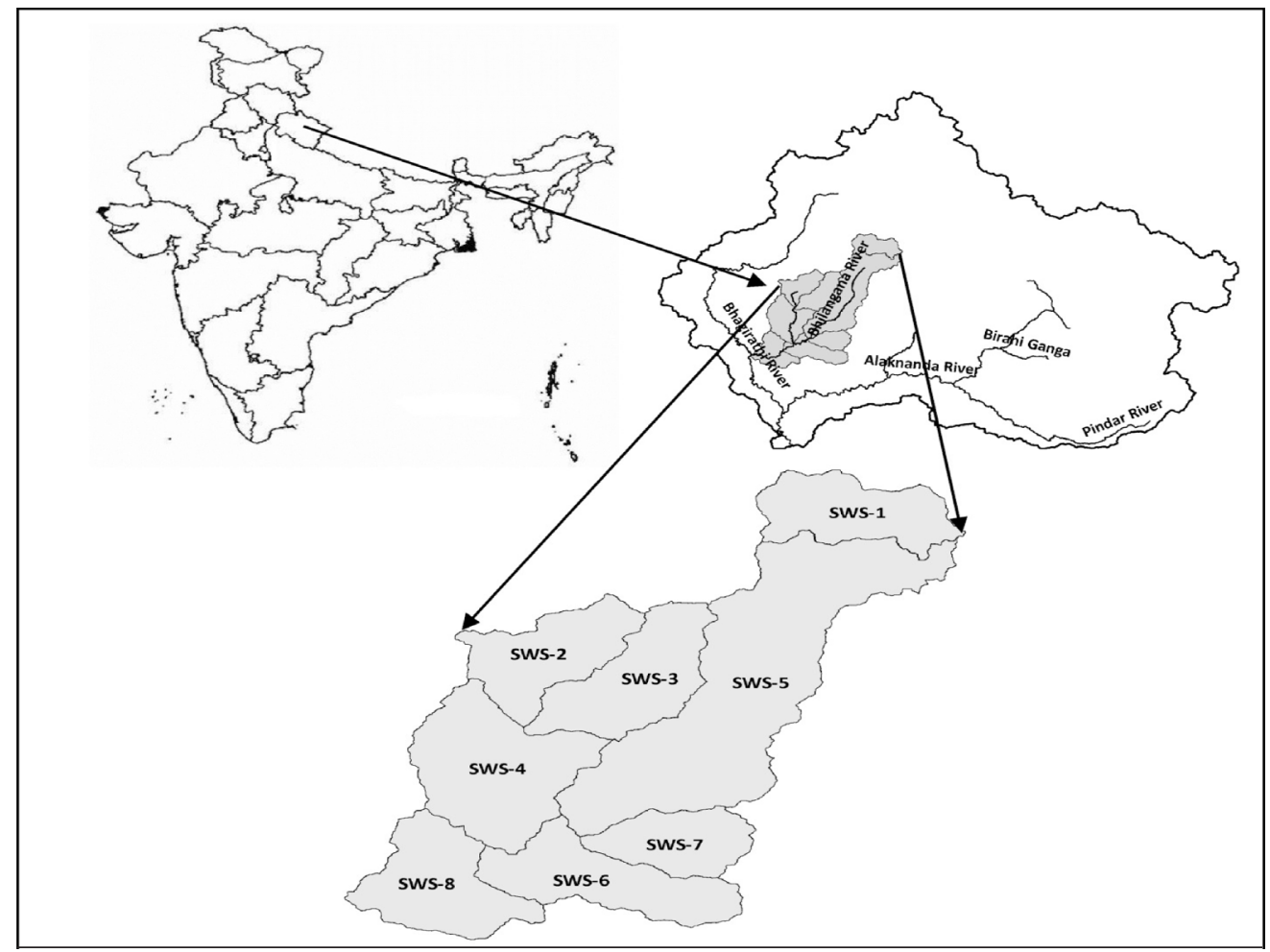

Figure 1. Location map of the study area.

including linear aspects of the drainage network such as stream order, bifurcation ratio, stream length of the basin, etc. were computed. Similarly, areal aspects of the drainage basin such as drainage density, stream frequency, texture ratio, elongation ration, circulatory ratio, form factor, etc. were computed. The morphometric parameters were computed using the formulae developed by different researchers as presented in Table 1.

Based on the computation and analysis of geomorphological parameters for different micro-basins, priority ranking is done for the eight micro-basins for eight morphological parameters viz. bifurcation ratio $\left(R_{b}\right)$, drainage density $\left(D_{d}\right)$, stream frequency $\left(F_{s}\right)$, texture ratio $\left(R_{T}\right)$, form factor $\left(F_{f}\right)$, circulatory ratio $\left(R_{c}\right)$, elongation ratio $\left(R_{e}\right)$ and compactness constant $\left(\mathrm{C}_{\mathrm{c}}\right)$. Prioritization of all the eight micro-basins is carried out by calculating the 'compound parameter'. The micro-basin with the lowest compound parameter value is given highest priority and suggested for urgent conservation measures to check erosion.

\section{Results and Discussion}

The morphometric parameters can be broadly classified into the three categories: (1) Linear aspects of channel;
(2) Areal aspects of the basin; and (3) Relief aspects of the basin. The drainage characteristics of the basin considering linear, areal and relief aspects of the basin are discussed in subsequent sections.

\subsection{Linear Aspects of the Channel}

\subsubsection{Stream Order}

Stream ordering is the first step taken in any drainage basin analysis, where hierarchical ranking is done to existing streams of different extents and pattern. In the present study, ranking of streams has been carried out based on the method proposed by Strahler (1964). The study area is a $7^{\text {th }}$ order drainage sub basin covering an area of $1465.38 \mathrm{~km}^{2}$. The drainage map of the study area showing existing order of different extent and pattern is presented in Figure 2. Out of eight micro-basins, two (SWS-7, SWS-8) are of $7^{\text {th }}$ order, three (SWS-1, SWS2, SWS-5) are of $6^{\text {th }}$ order and three (SWS-3, SWS-4, SWS-6) are of $5^{\text {th }}$ order micro-basins. The total number of 4664 streams were identified of which 3566 are $1^{\text {st }}$ order streams, 865 are $2^{\text {nd }}$ order, 174 are $3^{\text {rd }}$ order, 43 are $4^{\text {th }}$ order, 9 in $5^{\text {th }}, 5$ in $6^{\text {th }}$ and 2 in $7^{\text {th }}$ order streams. The highest number of stream segments is found in micro-basin SWS-2 while the lowest number 
Table 1. Formulae adopted for computation of morphometric parameters

\begin{tabular}{|c|c|c|c|}
\hline Sl No. & Morphometric Parameters & Formula & Reference \\
\hline 1. & Stream order & Hierarchical rank & Strahler (1964) \\
\hline 2. & Stream length $\left(\mathrm{L}_{\mathrm{u}}\right)$ & Length of the stream & Horton (1945) \\
\hline 3. & Mean stream length $\left(\mathrm{L}_{\mathrm{sm}}\right)$ & $\begin{array}{c}\mathrm{L}_{\mathrm{sm}}=\mathrm{L}_{\mathrm{u}} / \mathrm{N}_{\mathrm{u}} \\
\text { Where, } \mathrm{L}_{\mathrm{u}}=\text { Total stream length of order ' } \mathrm{u} \text { ' } \\
\mathrm{N}_{\mathrm{u}}=\text { Total number of stream } \\
\text { segments of order ' } \mathrm{u} \text { ' }\end{array}$ & Strahler (1964) \\
\hline 4. & Stream length ratio $\left(R_{1}\right)$ & $\begin{array}{c}\mathrm{R}_{\mathrm{l}}=\mathrm{L}_{\mathrm{u}} / \mathrm{L}_{\mathrm{u}-1} \\
\text { Where, } \mathrm{L}_{\mathrm{u}}=\text { Total stream length of order ' } \mathrm{u} \text { ' } \\
\mathrm{L}_{\mathrm{u}-1}=\text { Total stream length of its next } \\
\text { lower order }\end{array}$ & Horton $(1945)^{10}$ \\
\hline 5. & Bifurcation ratio $\left(\mathrm{R}_{\mathrm{b}}\right)$ & $\begin{array}{c}\mathrm{R}_{\mathrm{b}}=\mathrm{N}_{\mathrm{u}} / \mathrm{N}_{\mathrm{u}+1} \\
\text { Where, } \mathrm{N}_{\mathrm{u}}=\text { Total no. of stream segments of order ' } \mathrm{u} \text { ' } \\
\mathrm{N}_{\mathrm{u}+1}=\text { Number of segments of the } \\
\text { next higher order }\end{array}$ & Schumm $(1956)^{22}$ \\
\hline 6. & Relief ratio $\left(\mathrm{R}_{\mathrm{h}}\right)$ & $\begin{array}{c}\mathrm{R}_{\mathrm{h}}=\mathrm{H} / \mathrm{L}_{\mathrm{b}} \\
\text { Where, } \mathrm{H}=\text { Relative relief of the basin, } \mathrm{km} \\
\mathrm{L}_{\mathrm{b}}=\text { Basin length, } \mathrm{km}\end{array}$ & Schumm (1956) \\
\hline 7. & Drainage density $\left(\mathrm{D}_{\mathrm{d}}\right)$ & $\begin{array}{c}\mathrm{D}_{\mathrm{d}}=\mathrm{L}_{\mathrm{u}} / \mathrm{A} \\
\text { Where, } \mathrm{L}_{\mathrm{u}}=\text { Total stream length of all orders } \\
\mathrm{A}=\text { Area of the basin, } \mathrm{km}^{2}\end{array}$ & Horton (1945) \\
\hline 8. & Stream frequency $\left(\mathrm{F}_{\mathrm{s}}\right)$ & $\begin{array}{c}\mathrm{F}_{\mathrm{s}}=\mathrm{N}_{\mathrm{u}} / \mathrm{A} \\
\text { Where, } \mathrm{N}_{\mathrm{u}}=\text { Total no. of streams of all orders } \\
\mathrm{A}=\text { Area of the basin, } \mathrm{km}^{2}\end{array}$ & Horton (1945) \\
\hline 9. & Texture ratio $\left(\mathrm{R}_{\mathrm{T}}\right)$ & $\begin{array}{c}\mathrm{R}_{T}=\mathrm{N}_{\mathrm{u}} / \mathrm{P} \\
\text { Where, } \mathrm{N}_{\mathrm{u}}=\text { Total no. of streams of all orders } \\
\mathrm{P}=\text { Perimeter of the basin, } \mathrm{km}\end{array}$ & Horton (1945) \\
\hline 10. & Form factor $\left(\mathrm{F}_{\mathrm{f}}\right)$ & $\begin{array}{c}\mathrm{F}_{\mathrm{f}}=\mathrm{A} / \mathrm{L}_{\mathrm{b}}^{2} \\
\text { Where, } \mathrm{A}=\text { Area of the basin, } \mathrm{km}^{2} \\
\mathrm{~L}_{\mathrm{b}}^{2}=\text { Square of basin length }\end{array}$ & Schumm $(1956)^{23}$ \\
\hline 11. & Circulatory ratio $\left(\mathrm{R}_{\mathrm{c}}\right)$ & $\begin{array}{l}\mathrm{R}_{\mathrm{c}}=4 \mathrm{x} \pi \mathrm{x} \mathrm{A} / \mathrm{P}^{2} \\
\text { Where, } \mathrm{A}=\text { Area of the basin, } \mathrm{km}^{2} \\
\mathrm{P}=\text { Square of the perimeter, } \mathrm{km}\end{array}$ & Miller $(1953)^{22}$ \\
\hline 12. & Elongation ratio $\left(\mathrm{R}_{\mathrm{e}}\right)$ & $\begin{array}{c}\mathrm{R}_{\mathrm{e}}=(4 \times \mathrm{A} / \pi)^{0.5} / \mathrm{L}_{\mathrm{b}} \\
\text { Where, } \mathrm{A}=\text { Area of the basin, } \mathrm{km}^{2} \\
\mathrm{~L}_{\mathrm{b}}=\text { Basin length, } \mathrm{km}\end{array}$ & Schumm (1956) \\
\hline 13. & Length of the overland flow $\left(\mathrm{L}_{\mathrm{o}}\right)$ & $\mathrm{L}_{\mathrm{o}}=1 / 2 \mathrm{D}_{\mathrm{d}}$ & Horton (1945) \\
\hline 14. & Compactness constant $\left(\mathrm{C}_{c}\right)$ & $\begin{array}{c}\mathrm{C}_{\mathrm{c}}=0.2821 \mathrm{x} \mathrm{P} / \mathrm{A}^{0.5} \\
\text { Where, } \mathrm{A}=\text { Area of the basin, } \mathrm{km}^{2} \\
\mathrm{P}=\text { Basin perimeter, } \mathrm{km}\end{array}$ & Horton (1945) \\
\hline
\end{tabular}

of stream segments is found in SWS- $6.1^{\text {st }}$ order and $2^{\text {nd }}$ order streams combinedly constitute $95 \%$ of the total stream segments. Drainage patterns of stream network from the sub basin have been observed as mainly parallel type indicating a hilly catchment. The order wise stream numbers, area and total stream segments of the eight micro-basins are presented in Table 2. It is further observed that maximum frequency is seen in case of $1^{\text {st }}$ order stream and it decreases as the stream order increases. The variation of stream number with stream order on semi-log plot is depicted in Figure 3. The negative slope of the plot confirms the law of stream numbers indicating reduction of number from lower to higher orders. 


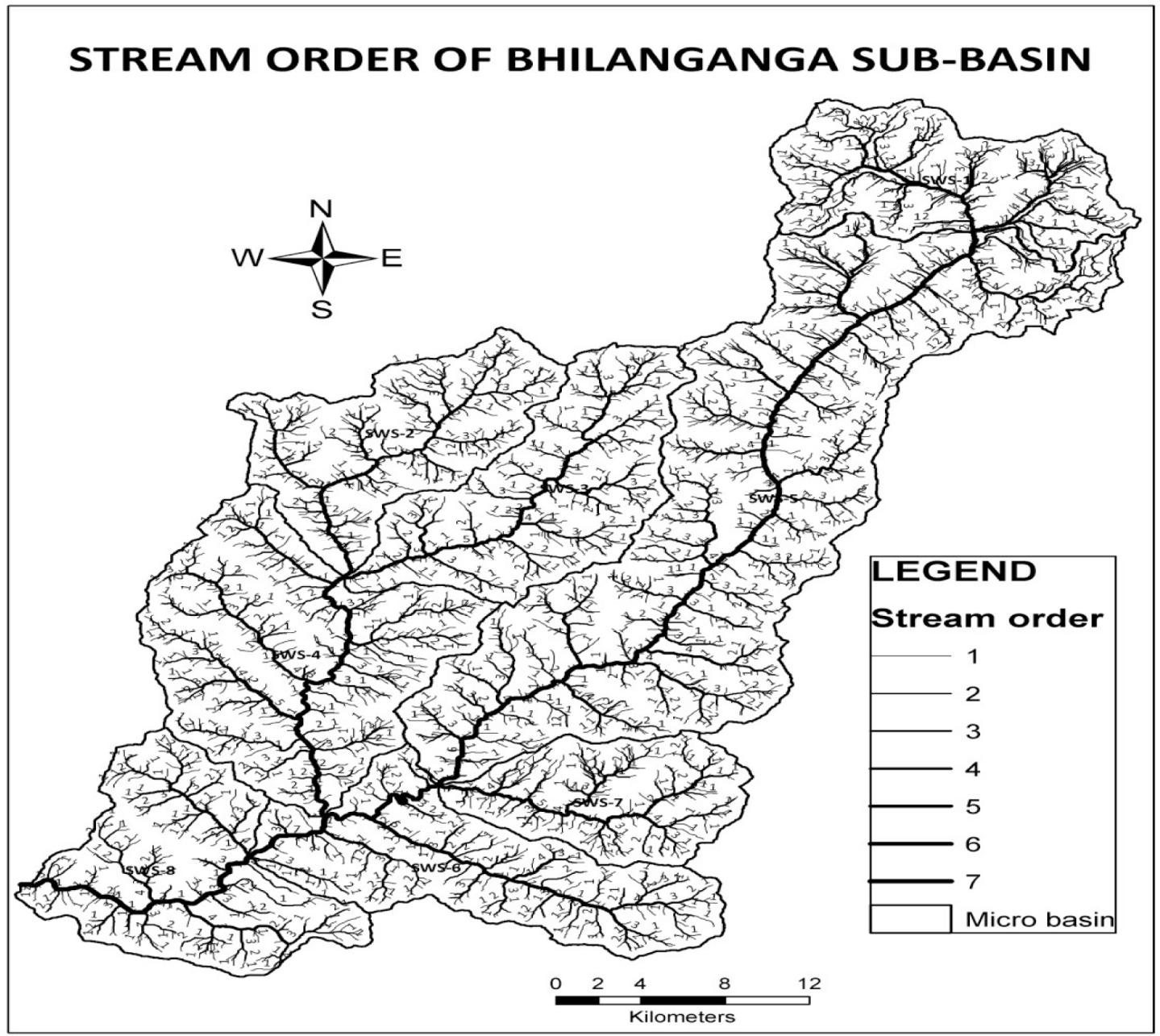

Figure 2. Drainage map of the study area showing stream ordering.

Table 2. Micro-basin wise stream order with number of segments

\begin{tabular}{lcccccccccc}
\hline S1 No. & $\begin{array}{c}\text { Micro } \\
\text { Basin } \\
\text { Name }\end{array}$ & $\begin{array}{c}\text { Micro Basin } \\
\text { Area }\left(\mathrm{km}^{2}\right)\end{array}$ & \multicolumn{9}{c}{ I } & II & III & IV & V & VI & VII & $\begin{array}{c}\text { Total } \\
\text { number } \\
\text { of stream } \\
\text { segments }\end{array}$ \\
\hline 1 & & & & & & & & & & \\
2 & SWS-1 & 124.30 & 349 & 91 & 17 & 6 & 2 & 1 & - & 466 \\
2 & SWS-2 & 465.29 & 1189 & 279 & 53 & 12 & 1 & 1 & - & 1535 \\
3 & SWS-3 & 149.18 & 356 & 83 & 18 & 5 & 1 & - & - & 463 \\
4 & SWS-4 & 129.68 & 316 & 93 & 14 & 3 & 1 & - & - & 427 \\
5 & SWS-5 & 210.82 & 485 & 111 & 20 & 5 & 1 & 1 & - & 623 \\
6 & SWS-6 & 91.91 & 228 & 61 & 14 & 5 & 1 & - & - & 309 \\
7 & SWS-7 & 148.29 & 313 & 67 & 18 & 4 & 2 & 2 & 1 & 407 \\
8 & SWS-8 & 145.91 & 330 & 80 & 20 & 3 & - & - & 1 & 434 \\
Total & & 1465.38 & 3566 & 865 & 174 & 43 & 9 & 5 & 2 & 4664 \\
& & - & $(76.46)$ & $(18.55)$ & $(3.73)$ & $(0.92)$ & $(0.19)$ & $(0.11)$ & $(0.04)$ & $(100.00)$ \\
\hline
\end{tabular}

Figure in parenthesis show percentage stream segments contributed by different order 


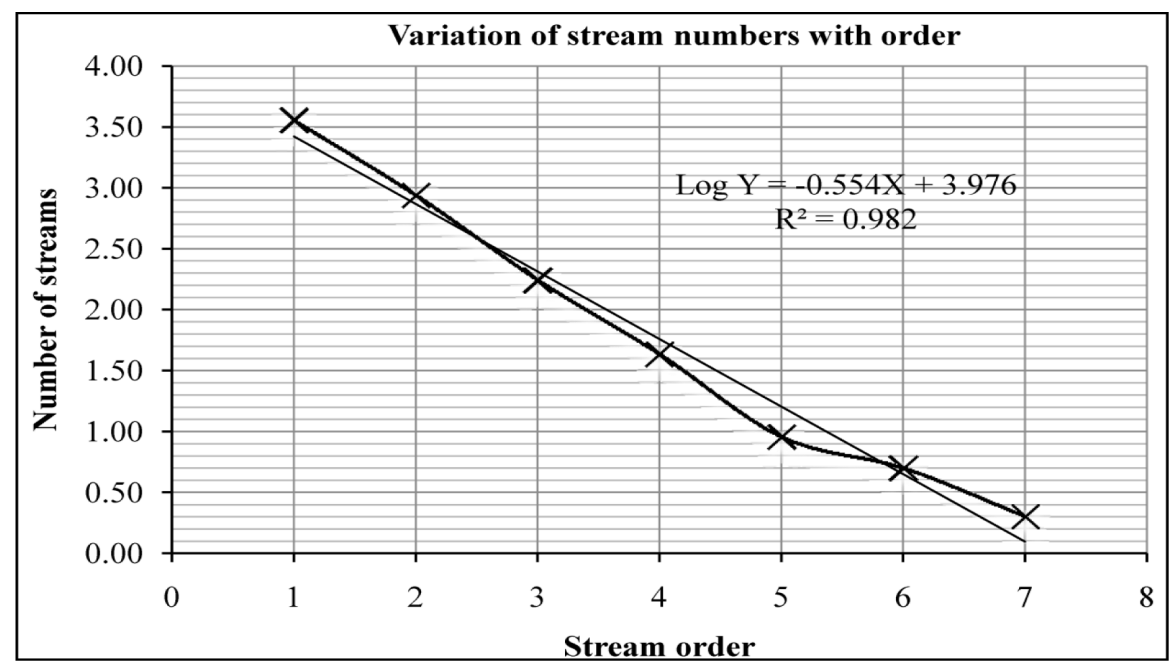

Figure 3. Plot showing variation of stream numbers with order.

\subsubsection{Stream length $\left(L_{u}\right)$}

Stream length is one of the most significant variables in a drainage basin characterizing runoff and basin features. It is an indicative of chronological developments of stream segments. Smaller length of streams are prominent in hilly areas with larger slopes where as longer streams are generally indicative of flat areas with lesser slope. The number of streams of various orders in the basin is counted and their lengths are measured using GIS technique. Semi-log plot of the variation of total stream lengths with stream orders is presented in Fig.4, indicating a negative slope of decreasing stream lengths with stream orders. The microbasins SWS- 2 and SWS- 5 show deviation from standard decreasing linear trend. This may be attributed to flowing of streams from high altitude and moderately steep slope of the micro-basin. The total length of $1^{\text {st }}$ and $2^{\text {nd }}$ order stream constitutes 75.49 percent of the total stream length. The order wise stream length and total stream lengths of the eight micro-basins are presented in Table 3.

\subsubsection{Mean stream length $\left(L_{s m}\right)$}

According to Strahler (1964), the stream length is a characteristic property related to the drainage network components and its associated basins. Mean stream length reveals the characteristic size of components of a drainage network and its contributing surfaces. In a drainage basin, mean stream length of a given order is higher than that of the lower order and less than that of its next higher order. The mean stream length is presented in Table 4. It is seen that, mean stream length in the study area varies from 0.393 to 10.510 with cumulative mean stream length of $42.074 \mathrm{~km}$.

\subsubsection{Stream length ratio $\left(R_{l}\right)$}

Stream length ratio is defined as the ratio between the mean stream lengths of one order with that of the next lower order of the stream segments. The stream length ratio between the streams of different orders of the study area does not follow any trend in different micro-basin. This change might be attributed to the variation in slope and topography, indicating the late youth stage of geomorphic development in the streams of the study area (Vittala et al., 2004). The stream length ratio between micro-basins showed an increasing trend in the length ratio from lower order to higher order excepting the order between IV/III and VII/VI indicating their mature geomorphic stage of development. The $\mathrm{R}_{1}$ values of different orders and micro-basins are presented in Table 5.

\subsubsection{Bifurcation $\left(R_{b}\right)$}

Bifurcation ratio describes the branching pattern of a drainage network and is defined as ratio between the total numbers of stream segments of a given order to that of the next higher order in a basin (Schumm, 1956). Bifurcation ratio generally ranges from 3.0 to 5.0 for basins in which geologic structures do not distort the drainage pattern (Strahler, 1964). The $\mathrm{R}_{\mathrm{b}}$ in the drainage sub-basin varies from 1.800 to 4.971 indicating that all the micro-basins are falling under normal basin category. The bifurcation ratio is also an indication of shape of the basin. An 


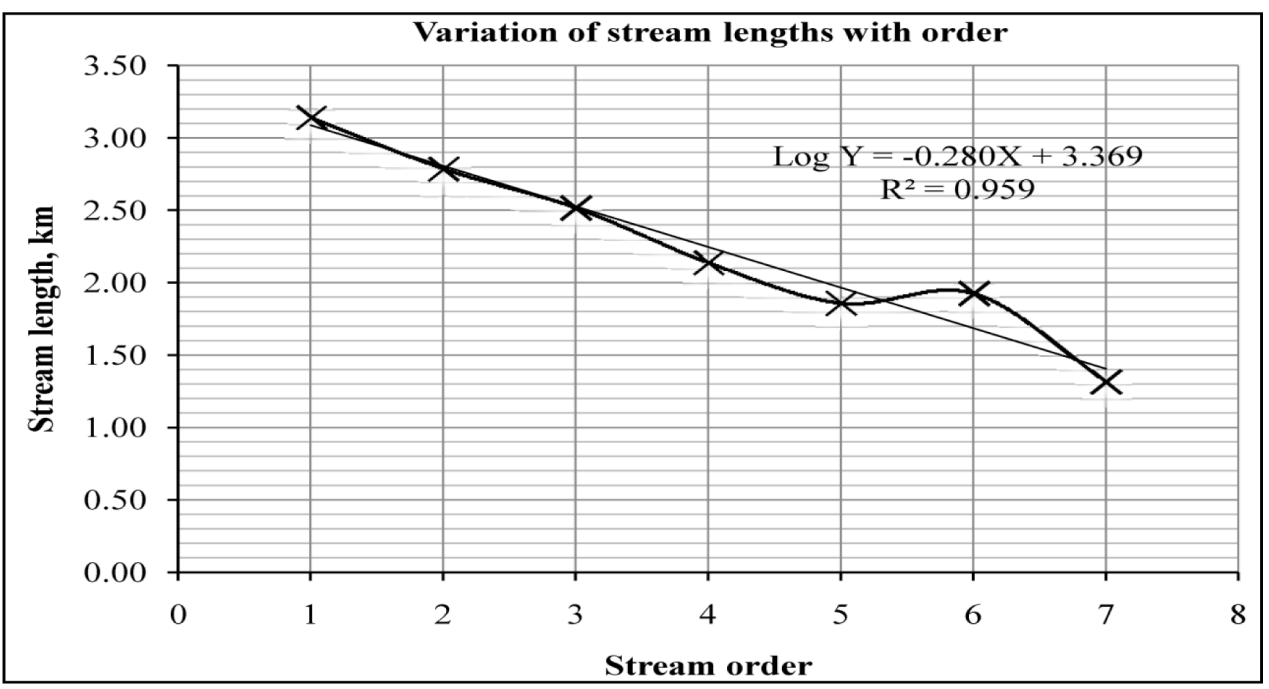

Figure 4. Plot showing variation of stream lengths with order.

Table 3. Micro-basin wise stream order with stream length

\begin{tabular}{lcccccccccc}
\hline S1 No. & Micro Basin & Micro Basin & \multicolumn{9}{c}{ Stream length, km } & Total of stream \\
\cline { 5 - 9 } & Name & Area $\left(\mathrm{km}^{2}\right)$ & I & II & III & IV & V & VI & VII & length \\
\hline 1 & SWS-1 & 124.30 & 159.70 & 69.16 & 41.89 & 10.46 & 9.78 & 0.02 & - & 291.01 \\
2 & SWS-2 & 465.29 & 448.56 & 185.65 & 113.06 & 42.09 & 3.61 & 54.83 & - & 847.80 \\
3 & SWS-3 & 149.18 & 128.27 & 61.23 & 29.98 & 12.74 & 18.41 & 0.00 & - & 250.63 \\
4 & SWS-4 & 129.68 & 125.27 & 56.39 & 28.34 & 14.47 & 10.72 & 0.00 & - & 235.70 \\
5 & SWS-5 & 210.82 & 194.38 & 85.29 & 43.51 & 21.95 & 4.50 & 21.57 & - & 371.20 \\
6 & SWS-6 & 91.91 & 100.96 & 42.21 & 15.12 & 11.12 & 11.95 & - & - & 181.36 \\
7 & SWS-7 & 148.29 & 123.52 & 58.59 & 28.19 & 11.46 & 14.41 & 9.26 & 5.52 & 250.95 \\
8 & SWS-8 & 145.91 & 121.83 & 63.10 & 34.14 & 15.22 & - & - & 15.50 & 249.79 \\
Total & & 1465.38 & 1403.00 & 621.62 & 334.23 & 139.51 & 73.38 & 85.68 & 21.02 & 2678.44 \\
& & - & $(52.28)$ & $(23.21)$ & $(12.48)$ & $(5.21)$ & $(2.34)$ & $(3.20)$ & $(0.78)$ & $(100.00)$ \\
\hline
\end{tabular}

Figure in parenthesis show percentage stream length contributed by different order

Table 4. Micro-basin wise stream order with stream length

\begin{tabular}{lcccccccc}
\hline \multirow{2}{*}{ Sl No. } & Micro Basin & \multicolumn{7}{c}{ Mean stream length (Lsm), km } \\
\cline { 2 - 9 } & Name & I & II & III & IV & V & VI & VII \\
\hline 1 & SWS-1 & 0.458 & 0.760 & 2.464 & 1.743 & 4.890 & 0.015 & - \\
2 & SWS-2 & 0.377 & 0.665 & 2.133 & 3.508 & 3.610 & 54.830 & - \\
3 & SWS-3 & 0.360 & 0.738 & 1.666 & 2.548 & 18.410 & 0.000 & - \\
4 & SWS-4 & 0.398 & 0.606 & 2.024 & 4.823 & 10.720 & 0.000 & - \\
5 & SWS-5 & 0.401 & 0.768 & 2.176 & 4.390 & 4.500 & 21.570 & - \\
6 & SWS-6 & 0.443 & 0.692 & 1.080 & 2.224 & 11.950 & - & - \\
7 & SWS-7 & 0.395 & 0.875 & 1.566 & 2.865 & 7.205 & 4.630 & 5.520 \\
8 & SWS-8 & 0.369 & 0.789 & 1.707 & 5.073 & 0.000 & - & 15.500 \\
\multicolumn{2}{l}{ Mean stream length } & 0.393 & 0.718 & 1.921 & 3.244 & 8.153 & 17.135 & 10.510 \\
\hline
\end{tabular}


Table 5. Micro-basin wise stream length ratio

\begin{tabular}{lccccccc}
\hline \multirow{2}{*}{ SI No. } & Sub Basin Name & \multicolumn{7}{c}{ Stream length ratio $\left(\mathrm{R}_{1}\right)$} \\
\cline { 3 - 8 } & & II/I & III /II & IV/III & V/IV & VI/V & VII/VI \\
\hline 1 & SWS-1 & 0.433 & 0.606 & 0.250 & 0.935 & 0.002 & - \\
2 & SWS-2 & 0.414 & 0.609 & 0.372 & 0.086 & 15.188 & - \\
3 & SWS-3 & 0.477 & 0.490 & 0.425 & 1.445 & 0.000 & - \\
4 & SWS-4 & 0.448 & 0.503 & 0.511 & 0.741 & 0.000 & - \\
5 & SWS-5 & 0.439 & 0.510 & 0.505 & 0.205 & 4.793 & - \\
6 & SWS-6 & 0.418 & 0.358 & 0.735 & 1.075 & - & - \\
7 & SWS-7 & 0.474 & 0.481 & 0.407 & 1.257 & 0.643 & 0.596 \\
8 & SWS-8 & 0.518 & 0.541 & 0.446 & 0.000 & - & 0.000 \\
\multicolumn{2}{l}{ Bhilanganga sub-basin } & 0.443 & 0.538 & 0.417 & 0.546 & 1.168 & 0.245 \\
\hline
\end{tabular}

elongated basin is likely to have a high $\mathrm{R}_{\mathrm{b}}$, whereas a circular basin is likely to have a low $\mathrm{R}_{\mathrm{b}}$. The mean $\mathrm{R}_{\mathrm{b}}$ is highest in the SWS-8 micro-basin with $R_{b}$ value of 4.699 where as it is lowest in the micro-basin SWS-7 with $R_{b}$ value 2.897. In the study area, the higher value of $R_{b}$ indicates a strong structural control in the drainage pattern whereas the lower values indicate that the micro-basins are less affected by structural disturbances (Strahler, 1964). Slope of the trend line plotted on semi-log scale between stream segments and stream orders gives the average value of the bifurcation ratio of the basin. The regression coefficient (slope of the trend line) computed for each micro-basin has been presented in Table 6. The linear decreasing trend for each micro-basin is presented in Figure 5. In this study, it was found that the graph between log (cumulative length) vs stream order $(\mathrm{Nu})$ is nearly a straight fit line. It indicates that the ratio of cumulative stream length and stream order is a constant which also indicates the drainage network to be dendritic to sub dendritic. The $\mathrm{R}_{\mathrm{b}}$ values are also presented in Table 6.

\subsection{Areal Aspects of the Basin}

\subsubsection{Drainage Density $\left(D_{d}\right)$}

Drainage density is defined as the total length of streams of all orders per drainage area. It is an expression to describe the existing channel closeness in a basin. Density factor vary with climate, rock type, relief, infiltration rate, vegetation cover and landscape evolution processes. The drainage density of different sub-basins is given in the Table 7 (column III). Area with very resistant or permeable subsoil material, low relief and dense vegetation results in low drainage (Nag, 1998). Weak or impermeable subsurface material, mountainous relief and sparse vegetation results in high drainage density. The $D_{d}$ value of the area ranges from 1.68 to $2.34 \mathrm{~km} / \mathrm{km}^{2}$, which indicates a coarser drainage pattern. The overall drainage density of the basin is $1.83 \mathrm{~km} / \mathrm{km}^{2}$.

\subsubsection{Stream Frequency $\left(F_{s}\right)$}

Stream frequency or channel frequency is considered as the total number of stream segments of all orders per unit area. The value of stream frequency of the study area basin is 3.18. The stream frequency value has a positive correlation with the drainage density value, which shows an increase in channel numbers relating to the increase in $\mathrm{D}_{\mathrm{d}}$ value. The $\mathrm{F}_{\mathrm{s}}$ value of different sub-basins is shown in the Table 7 (column IV).

\subsubsection{Texture Ratio $\left(R_{T}\right)$}

Texture ratio or drainage texture signifies the relative spacing of drainage lines. It is considered as the number of stream segments of all orders present in per perimeter of that area (Horton, 1945). Classification of drainage density into five different textures was done by Smith (1950). The drainage density of less than 2 indicates a very coarse texture, 2 and 4 is related to coarse, 4 and 6 stands for moderate, 6 and 8 is considered as fine, and greater than 8 is taken as very fine drainage texture. In the present study, the drainage density is of very coarse to coarse drainage texture. Texture ratio in the basin varies from 4.73 (SWS7) to 8.34 (SWS-2) as indicated in Table 7 (column V).

\subsubsection{Form Factor $\left(F_{f}\right)$}

Schumm, 1956 defined form factor as the ratio of the area of the basin to the square of the basin length. The form factor value should be always greater than 0.78 to have a 


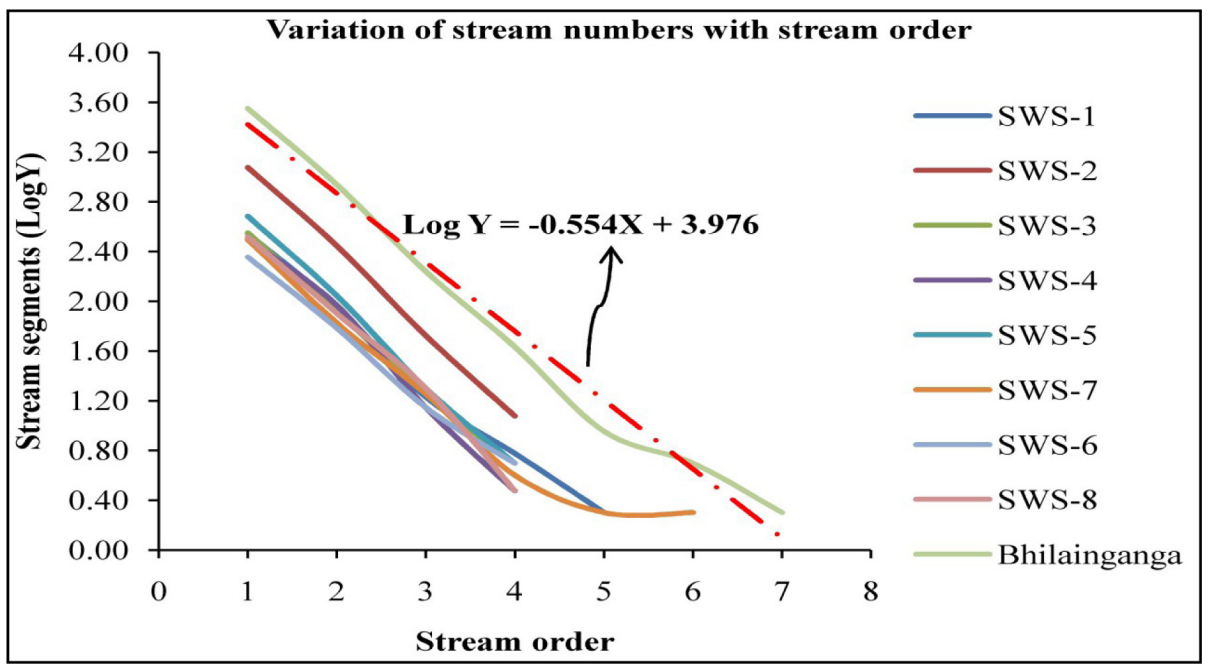

Figure 5. Plot showing variation of stream number with order of different micro-basins.

Table 6. Micro-basin wise bifurcation ratio

\begin{tabular}{|c|c|c|c|c|c|c|c|c|c|}
\hline \multirow[t]{2}{*}{ Sl no. } & \multirow{2}{*}{$\begin{array}{l}\text { Micro Basin } \\
\text { Name }\end{array}$} & \multicolumn{6}{|c|}{ Bifurcation ratio $\left(R_{b}\right)$} & \multirow{2}{*}{$\begin{array}{l}\text { Regression } \\
\text { coefficient }\end{array}$} & \multirow{2}{*}{$\begin{array}{c}\text { Mean bifurcation } \\
\text { ratio }\end{array}$} \\
\hline & & $\mathrm{I} / \mathrm{II}$ & II/III & III/IV & $\mathrm{IV} / \mathrm{V}$ & $\mathrm{V} / \mathrm{VI}$ & VI/VII & & \\
\hline 1 & SWS-1 & 3.835 & 5.353 & 2.833 & 3.000 & 2.000 & - & $(-) 0.566$ & 3.681 \\
\hline 2 & SWS-2 & 4.262 & 5.264 & 4.417 & 12.000 & 1.000 & - & $(-) 0.670$ & 4.677 \\
\hline 3 & SWS-3 & 4.289 & 4.611 & 3.600 & 5.000 & - & - & $(-) 0.622$ & 4.188 \\
\hline 4 & SWS-4 & 3.398 & 6.643 & 4.667 & 3.000 & - & - & $(-) 0.689$ & 4.887 \\
\hline 5 & SWS-5 & 4.369 & 5.550 & 4.000 & 5.000 & 1.000 & - & $(-) 0.670$ & 4.677 \\
\hline 6 & SWS-6 & 3.738 & 4.357 & 2.800 & 5.000 & - & - & $(-) 0.561$ & 3.639 \\
\hline 7 & SWS-7 & 4.672 & 3.722 & 4.500 & 2.000 & 1.000 & 2.000 & $(-) 0.462$ & 2.897 \\
\hline 8 & SWS-8 & 4.125 & 4.000 & 6.667 & - & - & - & $(-) 0.672$ & 4.699 \\
\hline \multicolumn{2}{|c|}{ Bhilanganga sub-basin } & 4.123 & 4.971 & 4.047 & 4.778 & 1.800 & 2.500 & $(-) 0.554$ & 3.581 \\
\hline
\end{tabular}

Figure in parenthesis show regression coefficient (slope) of the trend line (linear)

Table 7. Areal aspects of morphological parameters

\begin{tabular}{lcccccccc}
\hline S1 No. & $\begin{array}{c}\text { Micro Basin } \\
\text { Name }\end{array}$ & $\begin{array}{c}\text { Drainage } \\
\text { Density } \\
\left(\mathrm{D}_{\mathrm{d}}\right)\end{array}$ & $\begin{array}{c}\text { Stream } \\
\text { Frequency } \\
\left(\mathrm{F}_{\mathrm{s}}\right)\end{array}$ & $\begin{array}{c}\text { Texture } \\
\text { Ratio }\left(\mathrm{R}_{\mathrm{T}}\right)\end{array}$ & $\begin{array}{c}\text { Form } \\
\text { Factor } \\
\left(\mathrm{F}_{\mathrm{f}}\right)\end{array}$ & $\begin{array}{c}\text { Circularity } \\
\text { Ratio }\left(\mathrm{R}_{\mathrm{c}}\right)\end{array}$ & $\begin{array}{c}\text { Elongation } \\
\text { Ratio }\left(\mathrm{R}_{\mathrm{e}}\right)\end{array}$ & $\begin{array}{c}\text { Length of } \\
\text { overland } \\
\text { flow }\left(\mathrm{L}_{\mathrm{o}}\right)\end{array}$ \\
\hline$(\mathrm{I})$ & $(\mathrm{II})$ & $(\mathrm{III})$ & $(\mathrm{IV})$ & $(\mathrm{V})$ & $(\mathrm{VI})$ & $(\mathrm{VII})$ & $(\mathrm{VIII})$ & $(\mathrm{IX})$ \\
1 & SWS-1 & 2.341 & 3.749 & 6.274 & 0.373 & 0.283 & 0.690 & 0.854 \\
2 & SWS-2 & 1.822 & 3.299 & 8.336 & 0.151 & 0.172 & 0.439 & 1.098 \\
3 & SWS-3 & 1.680 & 3.104 & 5.824 & 0.283 & 0.296 & 0.601 & 1.190 \\
4 & SWS-4 & 1.818 & 3.293 & 5.621 & 0.370 & 0.282 & 0.687 & 1.100 \\
5 & SWS-5 & 1.761 & 2.955 & 6.890 & 0.396 & 0.324 & 0.710 & 1.136 \\
6 & SWS-6 & 1.973 & 3.362 & 5.729 & 0.414 & 0.397 & 0.726 & 1.014 \\
7 & SWS-7 & 1.692 & 2.745 & 4.734 & 0.272 & 0.252 & 0.589 & 1.182 \\
8 & SWS-8 & 1.712 & 2.974 & 5.642 & 0.466 & 0.310 & 0.770 & 1.168 \\
\multicolumn{2}{l}{$\begin{array}{l}\text { Bhilanganga } \\
\text { sub-basin }\end{array}$} & 1.828 & 3.183 & 15.681 & 0.275 & 0.208 & 0.592 & 0.274 \\
\hline
\end{tabular}


perfectly circular basin. The smaller form factor value will give more elongated basin. Table 7 (column VI) indicates that the $\mathrm{F}_{\mathrm{f}}$ values ranges from 0.151 to 0.466 signifying mainly elongated sub-basins in the study area. The elongated sub-basins with low value shows a flatter peak flow for long duration in the basin.

\subsubsection{Circulatory Ratio $\left(R_{c}\right)$}

Circulatory ratio is the ratio of the basin area to the area of a circle with the same perimeter as the basin (Miller, 1953). In the given basin area, $R_{c}$ values vary from 0.172 to 0.397 . Low $R_{c}$ values indicate mainly elongated subbasins (Table 7, column VII).

\subsubsection{Elongation Ratio $\left(R_{e}\right)$}

The elongation ratio is the ratio of the diameter of a circle of the same area as the drainage basin to the maximum length of the basin (Schumm, 1956). The values of the elongation ratio values generally vary from 0.6 to 1.0 over a large variety of climatic and geologic types (Rudraiah et al., 2008). The $R_{e}$ value in the present study ranges from 0.439 to 0.770 indicating high relief in the study area. Table-7 (column VIII) presents the elongation ratio of different sub-basins.

\subsubsection{Length of Overland Flow $\left(L_{o}\right)$}

It is the length of water over the ground before it gets concentrated into definite stream channels (Horton, 1945). The length of overland flow approximately equals to the reciprocal of drainage density. Table 7 (column IX) reveals that the $L_{o}$ values of the study area shows variation from 0.854 to 1.190 indicating comparatively high relief of the area.

\subsection{Relief Aspects of the Basin}

\subsubsection{Relief Ratio}

The elevation difference between the highest and lowest points on the valley floor of a basin is known as the total relief of that basin. The maximum relief to horizontal distance along the basin parallel to the principal drainage line is termed as relief ratio (Schumm, 1956). The relief ratio has direct relationship between the relief and channel gradient. In the study area, the values of relief ratio are ranging from 0.084 to 0.166 indicating high relief. The relief aspects of different micro-basins are presented in Table 8.

\subsection{Prioritization of Micro-basins}

Prioritization of micro-basins is done to identify critical zone with high erosion activities so that timely conservation measures can be taken for checking soil erosion in the area. The compound parameter values of all eight micro-basins of Bhilanganga sub-basin are computed and priority ranking is presented in Table 9.

The compound parameter is the weighted average of the eight morphological parameters as discussed in the methodology section. The micro-basin with lowest compound parameter is assigned the highest rank for priority erosion. Accordingly, the SWS-1 micro-basin with a compound parameter value of 3.50 is ranked highest in terms of erosion in the area followed by SWS-6, SWS-8, SWS-5, SWS-2 \& SWS-4, SWS-3 and SWS-7. Accordingly, conservation measures are sought starting from the micro-basin SWS-1 followed by other micro-basins depending upon their priority. The micro-basins SWS- 2 and SWS- 4 both have same priority ranking of fifth. A fully vegetated watershed/sub-basin can also be prioritized based on

Table 8. Relief aspects of morphological parameters

\begin{tabular}{lccccc}
\hline Sl No. & Micro Basin Name & Perimeter, km & Basin Length, km & Total Relief, km & Relief ratio \\
\hline 1 & SWS-1 & 74.280 & 18.250 & 3.034 & 0.166 \\
2 & SWS-2 & 184.140 & 55.430 & 4.858 & 0.088 \\
3 & SWS-3 & 79.500 & 22.940 & 3.497 & 0.152 \\
4 & SWS-4 & 75.960 & 18.710 & 2.935 & 0.157 \\
5 & SWS-5 & 90.420 & 23.080 & 2.008 & 0.087 \\
6 & SWS-6 & 53.940 & 14.900 & 2.097 & 0.141 \\
7 & SWS-7 & 85.980 & 23.330 & 1.965 & 0.084 \\
8 & SWS-8 & 76.920 & 17.700 & 2.034 & 0.115 \\
\multicolumn{2}{l}{ Bhilanganga sub-basin } & 297.42 & 72.950 & 6.080 & 0.083 \\
\hline
\end{tabular}


Table 9. Estimated Compound Parameter with Priority Ranking

\begin{tabular}{lccccccccccc}
\hline Sl No. & $\begin{array}{c}\text { Micro Basin } \\
\text { Name }\end{array}$ & $\mathrm{R}_{\mathrm{b}}$ & $\mathrm{D}_{\mathrm{d}}$ & $\mathrm{F}_{\mathrm{s}}$ & $\mathrm{R}_{\mathrm{T}}$ & $\mathrm{F}_{\mathrm{f}}$ & $\mathrm{R}_{\mathrm{c}}$ & $\mathrm{C}_{\mathrm{c}}$ & $\mathrm{R}_{\mathrm{e}}$ & $\begin{array}{c}\text { Compound } \\
\text { parameter }\end{array}$ & $\begin{array}{c}\text { Priority } \\
\text { ranking }\end{array}$ \\
\hline 1 & SWS-1 & 6 & 1 & 1 & 3 & 4 & 5 & 4 & 4 & 3.50 & 1 \\
2 & SWS-2 & 3 & 3 & 3 & 1 & 8 & 8 & 1 & 8 & 4.38 & 5 \\
3 & SWS-3 & 5 & 8 & 5 & 4 & 6 & 4 & 5 & 6 & 5.38 & 6 \\
4 & SWS-4 & 1 & 4 & 4 & 7 & 5 & 6 & 3 & 5 & 4.38 & 5 \\
5 & SWS-5 & 4 & 5 & 7 & 2 & 3 & 2 & 7 & 3 & 4.13 & 4 \\
6 & SWS-6 & 7 & 2 & 2 & 5 & 2 & 1 & 8 & 2 & 3.63 & 2 \\
7 & SWS-7 & 8 & 7 & 8 & 8 & 7 & 7 & 2 & 7 & 6.75 & 7 \\
8 & SWS-8 & 2 & 6 & 6 & 6 & 1 & 3 & 6 & 1 & 3.88 & 3 \\
\hline
\end{tabular}

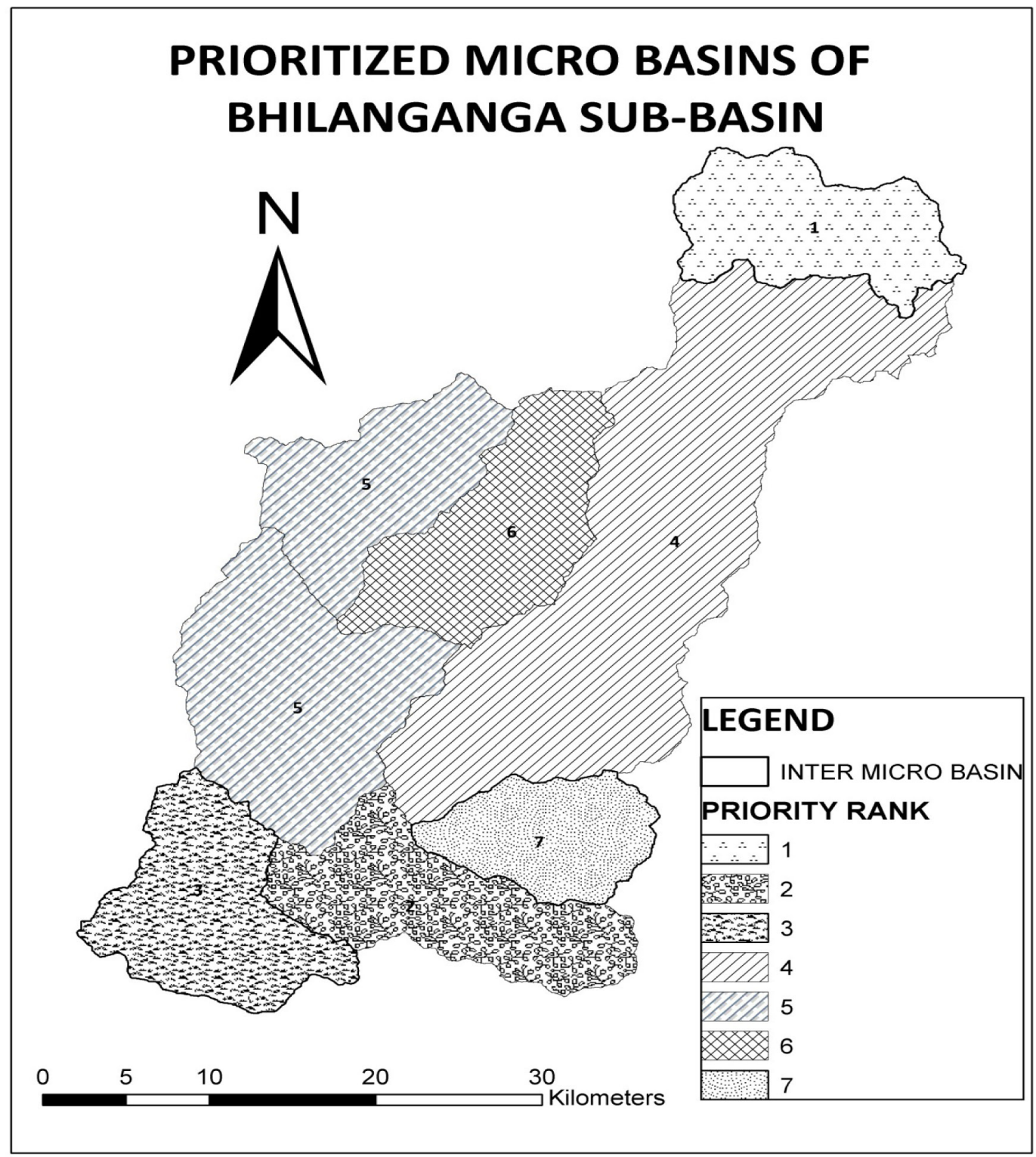

Figure 6. Map showing prioritized micro-basins with their corresponding ranks. 
morphometric parameters which are static in nature. This analysis leads only to the interpretation that the areas have the potential for prioritized erosion if disturbed. However, erosion may not be there if not disturbed. Thereby, the dynamic parameters such as land use, existing management practices also needs to be considered. Or else, soil data collected from the study area needs to be compared prior to coming into any conclusion for treatment practices. However, the present prioritization using morphological parameters is an indication to the degree of erosion in the micro-basins and helps in identifying the potential micro-basins for undertaking early measures for soil conservation. The final prioritized map of the study area showing different micro-basins with their priority ranking is presented in Figure 6.

\section{Conclusion}

In the present study morphological features of 'Bhilanganga' drainage sub basin are extracted utilizing satellite imagery and analyzed for assessing the drainage pattern. The morphometric analysis was carried out through measurement of linear, areal and relief aspects of the basin. The morphometric parameters were computed using ArcInfo software. GIS techniques with high accuracy of mapping and measurement is an efficient tool in morphometric analysis. The study area is a $7^{\text {th }}$ order drainage basin covering an area of $1465.38 \mathrm{~km}^{2}$. Out of eight micro-basins, two (SWS-7, SWS-8) are of $7^{\text {th }}$ order, three (SWS-1, SWS-2, SWS-5) are of $6^{\text {th }}$ order and three (SWS-3, SWS-4, SWS-6) are of $5^{\text {th }}$ order micro-basins. The law of lower the order higher the number of streams is implied throughout the basin. There is a decrease in the stream frequency with the increasing stream order. The basin area in the present study conforms to the Horton's law of stream numbers and stream lengths. The ratio of the stream length among the streams of different order of the study area shows a change in each micro-basin. The bifurcation ratio in micro-basins indicates normal basin category. The drainage density of the sub basin as a whole is $1.83 \mathrm{~km} / \mathrm{km}^{2}$ and suggest coarser drainage network. The values of form factor, circulatory ratio and elongation ratio suggest that most of the micro-basins are elongated in nature with high relief. Results of prioritization of micro-basins show that SWS- 1 and SWS- 6 are more prone to erosion with lowest value of compound parameter. The present prioritization is an indication to greater degree of erosion and attracts potential soil conservation measures. The authors suggest further analysis of soil erosion in the area for full-proof validation of the present prioritization arrived at. The present study demonstrated the utility of GIS techniques in prioritizing sub-watersheds, which may be helpful to water resource planner and decision makers to take suitable soil erosion control measures.

\section{Acknowledgement}

The authors, thankfully, acknowledges The Global Land Cover Facility (GLCF) centre for providing quality satellite image without which the study would not have been made possible. Lastly, we acknowledge our gratitude to Survey of India, Dehradun, India for procuring topographical maps which are used as the reference maps in the study.

\section{References}

1. Agarwal CS. Study of drainage pattern through aerial data in Naugarh area of Varanasi district, U.P. J of Indian Soc of Rem Sensing. 1998; 26:169-75.

2. Rudraiah M, Govindaiah S, Vittala SS. Morphometry using Remote Sensing and GIS techniques in the sub-basins of Kagna river basin, Gulbarga district, Karnataka, India. J of Indian Soc of Rem Sensing. 2008; 36:351-60.

3. Malik M, Bhat M, Kuchay NA. Watershed based drainage morphometric analysis of Lidder catchment in Kashmir valley using Geographical Information System. Recent Res in Sci and Tech. 2011; 3(4):118-26.

4. Okumura M, Araujo AG. Long-term cultural stability in hunter-gatherers: a case study using traditional and geometric morphometric analysis of lithic stemmed bifacial points from Southern Brazil. J Archaeol Sci. 2014; 45: 59-71.

5. National Institute of Hydrology 1998. Representative basin studies: morphometric analysis of Suddagedda basin, Andhra Pradesh. CS(AR)-24/97-98, NIH, Roorkee.1998; 29.

6. Pandey A, Mathur A, Mishra SK, Mal BC. Soil erosion modeling of a Himalayan watershed using RS and GIS. Environmental Earth Sciences. 2009; 59(2):399-410. Doi:10.1007/s12665-009-0038-0

7. Chatterjee S, Krishna AP, Sharma P. Geospatial assessment of soil erosion vulnerability at watershed level in some sections of the Upper Subarnarekha river basin, Jharkhand, India. Environmental Earth Sciences. 2013; 71(1):357-74. Doi:10.1007/s12665-013-2439-3

8. Ratnam KN, Rao VV, Amminedu E. Check dam positioning by prioritization of micro-watersheds using syi model 
and morphometric analysis - remote sensing and gis perspective. 2005; 33(1):25-38.

9. Nag SK. Morphometric analysis using Remote Sensing techniques in the Chaka sub-basin, Purulia district, West Bengal. J of Indian Soc of Rem Sensing. 1998; 26:69-76.

10. Horton RE. Erosional development of streams and their drainage basins: hydro-physical approach to quantitative morphology. Bulletin of Geo Soc of Am. 1945; 56:275-370.

11. Smith KG. Standards for grading textures of erosion topography. Am J Sci. 1950; 248:655-68.

12. Maxwell JC. The bifurcation ratio in Horton's law of stream numbers. Trans Am Geophysical Union. 1955; 36:520.

13. Nautiyal MD. Morphometric analysis of a drainage basin using aerial photographs: A case study of Khairkuli basin, district Dehradun, U.P. J of Indian Soc of Rem Sensing. 1994; 22(4):251-61.

14. Vittala SS, Govindaiah S, Gowda HH. Morphometric analysis of sub-watersheds in the Pavagada area of Tumkur district, South India using Remote Sensing and GIS techniques, J of Indian Soc of Rem Sensing. 2004; 32(4):351-62.

15. Nageswar RK, Latha S, Kumar PA, Krishna MH. Morphometric analysis of Gostani river basin in Andhra Pradesh state, India, using Spatial Information Technology. Int J of Geomatics and Geosci. 2010; 1(2):179-87.

16. Mishra S. Nagarajan R. Morphometric analysis and prioritization of sub-watersheds using GIS and Remote Sensing techniques: A case study of Odisha, India. Int J of Geomatics and Geosci. 2010; 1(3):501-10.

17. Malik MI, Baht MS, Kuchay NA. Watershed based drainage morphometric analysis of Lidder Catchment in Kashmir valley using geographical information system. Rec Res Sci Technol. 2011; 3:118-26

18. Chopra R, Dhiman RP. Sharma PK. Morphometric analysis of sub-watersheds in Gurdaspur district, Punjab using Remote Sensing and GIS techniques. J of Indian Soc of Rem Sensing. 2005; 33(4):531-9.

19. Mani P, Kumar R, Chatterjee C. Erosion Study of a Part of Majuli River-Island Using Remote Sensing Data. 2003; 31(1):12-18.

20. Javed A, Yousuf M, Rizwan K. Prioritization of Subwatersheds based on Morphometric and Land Use Analysis using Remote Sensing and GIS Techniques. Journal of the Indian Society of Remote Sensing 2009; 261-74.

21. Shrimali SS, Aggarwal SP, Samra JS. Prioritization erosionprone areas in hills using remote sensing and GISA case study of Sukhna Lake catchment. Northern India. Internat Journ Applied Earth Obervation and Geoinformatics. 2001; 3(1):54-60.

22. Miller VC. A quantitative geomorphic study of drainage basin characteristics in the clinch mountain area, Varginia and Tennessee. Project NR. 389-042, Tech Rept 3. Columbia University, Dept. of Geology, ONR, Geography Branch: New York; 1953.

23. Schumm SA. Evaluation of drainage systems and slopes in badlands at Perth Amboy, New Jersy. Bull Geol Soc Amer. 1956; 67:597-646.

24. Strahler AN. Quantitative analysis of watershed geomorphology. Trans of Am Geophysical Union. 1957; 38(6):913-20. 